\title{
An Examination Of The Current State Of Accounting Information Systems Education
}

Thomas G. Calderon, tcalderon@uakron.edu, University of Akron John J. Cheh, cheh@uakron.edu, University of Akron

Michael D. Chatham, chatham@uakron.edu, University of Akron

\begin{abstract}
This paper reviews several factors that drive the need for a closer examination of accounting information systems (AIS) education and provides an assessment of the current state of AIS education in the US. The assessment draws from two separate sets of guidelines for AIS education, published by the American Institute of Certified Public Accountants and Information Systems Audit and Control Association. These guidelines are used because they were developed by professionals in the field, with input from academics, and represent publicly available, coherent attempts to identify a body of AIS knowledge for accountants and auditors. We surveyed undergraduate and masters programs offered in all accounting departments with separate AACSB-accounting accreditation. Our survey found very few degree programs or concentrations in AIS as well as a considerable amount of diversity among existing programs. Consistent with Christensen's innovation dilemma (1997), we speculate that the traditional absence of a focused, coherent attempt to develop and promote accounting information systems as an academic discipline may be one of the critical factors that contributes to the slow diffusion of AIS programs in business schools
\end{abstract}

\section{Introduction}

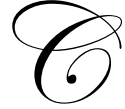

omputers are now a key resource in accounting and financial information processing. Furthermore, major advances in information technology (Seligman, 2000) as well as the existence of observable and tangible economic benefits (Botosan, 1997 and Seligman, 2000) have driven traditional auditing and financial reporting ever closer to being real-time tasks. Companies like Cisco Systems have made significant progress in making real-time financial reporting a reality (Selignam, 2000). Seligman (2000, p.148) reports that "Cisco Systems is one of the rare companies today in which the boss can clap his hands and get the books closed within an hour."

The emergence of computer information technology has also affected the business practices of large accounting and professional services organizations such as the "Big Five" and their spin-offs (e.g., Accenture). Computers are ubiquitous in the work of accountants and auditors, and accounting professionals view information systems as a major growth area within the profession. Among the observations of Albrecht and Sack (2000) is the need for change in accounting education due to the emergence and the importance of information technology (IT). As information systems take center stage in collecting, validating, storing, processing, and disseminating financial data and information, it becomes increasingly necessary to examine the current state of accounting information systems education.

Readers with comments or questions are encouraged to contact the authors via email. 
This paper reviews several factors that drive the need for a closer examination of AIS education and provides an assessment of the current state of AIS education nationally. The assessment is based on two separate sets of guidelines for AIS education, published by the American Institute of Certified Public Accountants' (AICPA, 2000e) and Information Systems Audit and Control Association (ISACA, 2000). These guidelines were selected because they were developed by professionals in the field, with input from academics, and represent publicly available, coherent attempts to identify a body of AIS knowledge that responds to new challenges facing accountants and auditors. The remainder of the paper is subdivided into a background section that provides a review of the literature and identifies the specific research questions examined, a section that describes the methodology employed, a section that presents the findings, and finally a conclusion and discussion section.

\section{Background}

This section describes forces that drive the need for a reexamination of AIS education and examines proposals by ISACA and the AICPA for elevating the level of IT preparation for accountants, auditors and assurance services providers, and information systems consultants. The section concludes with a list of specific research questions examined in the paper.

\section{Need for Reexamination of AIS Education}

Though there are many market forces helping to bring IT to the center stage of accounting education, this paper discusses the following five factors:

1. The emergence of the World Wide Web and e-commerce in association with AICPA's commitment to provide risk assurance services for e-commerce (AICPA, 2001 a);

2. The AICPA's embracement of IT and its commitment to take a leadership role in IT services affecting the business community (AICPA, $2001 \mathrm{~b}$ );

3. Increasing demands by the business and investing communities for timely financial reporting (SEC, 2000 b) and an apparently strong desire for real-time financial reporting (Seligman, 2000);

4. Urgent needs for training new types of information systems (IS) auditors so that they are equipped with strong backgrounds in accounting and information systems, in part to support timely financial reporting and eventual real-time financial reporting (ISACA, $2000 \mathrm{c}$ );

5. The changing nature of financial information systems processing due to continuous technological innovations (Zweig et al., 1996).

\section{The Web and e-commerce}

In recent years, the emergence of the World Wide Web brought to the business community the possibility of collecting, storing, retrieving, analyzing, and communicating financial information in unprecedented ways. The Web also facilitated the growth in business-to-business and business-to-consumer e-commerce, with speed, convenience, and buyer empowerment being among the most significant advantages of this new business model. On the other hand, e-commerce is vulnerable to several threats, including buyer and seller identity and authentication issues, poor order fulfillment practices, concerns about privacy and confidentiality, data transmission errors and interception, denial of service attacks, and unreliable payment mechanisms. Recognizing this, the AICPA initiated risk assurance services (AICPA, 2001 a) for e-commerce (e.g., WebTrust) to assist its members in providing such services. The performance of quality risk assessment and assurance services in this environment requires new types of knowledge for existing accountants - and changes the nature of accounting education for future graduates interested in performing risk assurance services, putting even more emphasis on acquiring an IT knowledge-base.

\section{The AICPA's embracement of IT}

The AICPA has also been active in promoting the leadership role of accountants as quality IT professionals in the business community (AICPA, $2001 \mathrm{~b}$ ). The AICPA notes that professional accountants play diverse roles that require them to interface with IT (AICPA, 2000 e). These roles include information technology user, information 
systems manager, business systems designer, and information systems evaluator/auditor. The rapid advancement of IT demands that various types of professional accountants, regardless of their specific roles, master a growing body of IT knowledge and develop expertise sufficient to provide quality information systems services. In order to support this varying role of professional accountants as business solutions providers using IT, the AICPA's Center For Certified Information Technology Professionals recognizes CPAs as Certified Information Technology Professionals (CITP) via its certification program (http://citp.aicpa.org/homepage.htm). Again recognizing IT as an integral part of accounting, the AICPA also supports the International Federation of Accountants (IFAC) guideline that accounting education must incorporate increasing amounts of IT (AICPA, $2000 \mathrm{~d}$ ). One of the objectives of the IFAC guideline is to provide accounting faculty with a model for integrating IT and traditional accounting topics.

\section{Real-time financial reporting}

Although real-time financial reporting provides benefits to investors and financial analysts, prior discussion regarding the use of technologies that would bring the business community closer to real-time financial reporting has raised several concerns. For instance, when Cushing (1989) wrote about the emergence of the Securities and Exchange Commission's EDGAR (Electronic Data Gathering, Analysis, and Retrieval) system (SEC, 2000 a), he examined the feasibility and consequences of using a database approach to corporate financial reporting.

The database approach is a precursor to the current Internet client/server based portal approach. At the time of Cushing's work, the World Wide Web did not exist, and Bernard-Lee's HTML (W3, 2000) was not yet invented. Nonetheless, the issues addressed by Cushing are still relevant and point to a need for reexamination of the content of accounting information systems education. In his work, Cushing found that the database approach would be feasible for financial reporting. Yet, he also recognized that this approach would have varying economic effects on several players in the economy. One of his observations dealt with which players might support the database approach and which ones might oppose it. Cushing (1989) conjectured that the most likely supporters of the database approach would be governmental agencies involved in regulatory enforcement, accounting scholars, and the data processing industry. On the other hand, the most likely opponents might be corporate management, corporate accountants, financial analysts, and investors with private access to inside information.

Cushing (1989) argued that corporate management might object to the database approach because it would hinder their ability to manipulate financial information in a manner that best serves their self-interest. Cushing believed that the database approach would enable meticulous monitoring and appraisal of management's accounting choices. As a result, he reasoned that this approach would almost certainly lead to restrictions in these choices, and that corporate management might experience a significant reduction in their ability to manage earnings. Similar arguments could be made about real-time financial reporting in the context of today's environment as it could lead to greater transparency in financial reporting and enable more efficient monitoring of management's accounting method choices.

Since 1989, technological advancements and the World Wide Web have transformed the way users of financial reports seek financial information and how corporations have supported (albeit selectively), through their web pages, users' demand for timely information. The emergence of the World Wide Web has also made the "nearly real-time" financial reporting convenient and economical for individual investors. Constantly updated World Wide Web pages have shown investors that they may have the opportunity to acquire financial information on a real-time basis.

It might be argued that the cost of disclosing information real-time and/or the fear of passing on proprietary information to competitors might discourage companies from disclosing their financial information in a real-time manner. However, these disadvantages might be offset by the impact of timely disclosures on the cost of capital. Botosan (1997) found that the cost of capital is lower for companies (particularly smaller entities) that provide more thorough and timely financial disclosure than those companies that do not. Botosan's findings provide some insight into the potential benefits that might accrue from real-time financial reporting.

Overall, it seems evident that developments in real-time reporting have the backing of the financial community and that the technology currently exists, or is being developed, to facilitate this new model of financial re- 
porting. Changes in both the reporting model and the information technology enabling such changes suggest a need to examine the current state of AIS education.

Assurance services for real-time reporting

The quality and effectiveness of real-time financial reporting is contingent upon the ability to provide realtime, continuous financial auditing. Continuous auditing has been defined as "a methodology that enables independent auditors to provide written assurance on a subject matter using a series of auditors' reports issued simultaneously with, or a short period of time after, the occurrence of events underlying the subject matter" (CICA/AICPA, 1999). Continuous auditing requires a high degree of automation. It is also dependent upon (a) precise definitions of the data underlying the items to be audited, (b) use of real-time controls to signal errors and irregularities, and (c) automated integrated audit agents and other technologies that enable collection, analysis, summarization, and reporting of audit evidence and opinions. Like real-time financial reporting, real-time, continuous auditing also creates a need for a new breed of accounting information systems professionals who are not only well-versed in traditional audit and accounting methods, but also information technology (IT).

\section{Changing nature of financial information systems and enabling technologies}

The possibility of sharing very timely financial data and information on the Web has accelerated many new developments in financial reporting that have the active support of the corporate community. One such significant breakthrough is XBRL (Extensible Business Reporting Language, 2000), a variation of XML (Extensible Markup Language), for financial reporting. XBRL is expected to make it easier to locate, retrieve, and use financial data that are published on the Web. Moreover, by establishing penalties for private, preemptive disclosure of financial information to exclusive groups such as financial analysts, the recent SEC fair disclosure ruling provides additional impetus for advances in real-time reporting to the entire business and investing community (Seligman, 2000). Corporations may now attempt to make timely (including real-time) information available to all market participants rather than select groups of analysts and investment bankers.

In order to reach a distributed audience, real-time financial reporting and auditing require sophisticated network technology and Web-based systems. As advances in real-time financial reporting and auditing continue, a new breed of accounting practitioners and accounting scholars may question and subsequently reexamine some of the fundamental assumptions made under the guise of manual systems usage during most of the last century. As demonstrated by EDGAR (SEC, 2000 a) and other media available via the World Wide Web, the fundamental assumptions underlying modern accounting may need to be thoroughly reexamined in this post-modern age in which the media for financial communication is no longer confined to a linear time frame, but rather is capable of accommodating spatial data points within dynamic financial transactions.

\section{Recommended AIS Curricular And Body Of Knowledge}

To assist educators in dealing with this new emerging breed of information services professionals, both the ISACA and the AICPA provide useful recommendations. Both sets of recommendations are presented in this section.

\section{ISACA's Model Curriculum}

ISACA (2000 c) has proposed both an undergraduate and a graduate model curriculum for AIS education. ISACA discusses its proposal for a model IS auditing education curricula and its objective in doing so as follows (ISACA, $2000 \mathrm{c}$ ):

"The purpose of this model is to propose IS auditing curricula at the undergraduate and graduate levels. The model is based on the needs and the expectations of the IS auditing profession and the prior research of academicians, practitioners, audit organizations and professional societies.... The goals of the model curricula are to prepare students for careers in the IS auditing profession and to assist students in becoming marketable in the auditing profession. The COBIT: Framework ... and 1996 CISA [Certified Information Systems Audit] domains ... were used as a guide to 
structure the core IS audit, security, and control courses at both the undergraduate and graduate levels.... Although undergraduates may not possess actual work experience, the core courses are designed to provide the candidate with entry-level skills and capability."

The undergraduate and graduate model AIS curricula are discussed below.

ISACA's undergraduate model curriculum

ISACA's rationale behind proposing the undergraduate model curriculum is described as follows (ISACA, $2000 \mathrm{c}$ ):

"Employers are demanding that their accounting and audit professionals possess adequate backgrounds in computer science and IS. Typically, the student at this level lacks business experience and seeks to gain the required knowledge, skills, and abilities through academic/ business course work enhanced by internships. Traditional undergraduate accounting programs appear inadequate to meet these needs. The common approach is that after students take general business courses (i.e., marketing, business law), students take elective courses in IS or a single accounting IS course, usually without coordination of course content between the two disciplines.

The proposed undergraduate model is interdisciplinary in nature, and may require resources from two or more departments or schools within a university. This is a very positive aspect of the model. Interdisciplinary programs between the departments within a university and between schools of business and other universities are highly encouraged by the American Assembly of Collegiate Schools of Business (AACSB) and other accrediting bodies in the US. In Europe, the proposed Postgraduate Curriculum in Information Security, Dependability and Safety is one example of universities sharing resources to offer postgraduate education in this field."

The ISACA's proposed courses fall into three groups: (1) Accounting, (2) Information Systems (IS), and (3) Internal Auditing. Specifically, the undergraduate AIS model curriculum emphasizes the topical coverage listed in Table 1. This model curriculum provides a blend of twelve courses from three disciplines - accounting, information systems, and auditing - and provides adequate opportunity for students at most universities to complete general education and core business courses.

Table 1

ISACA's Undergraduate Model Curriculum for Certified Information Systems Audit (CISA) Professionals

\begin{tabular}{|l|l|}
\hline Domain Area & Courses \\
\hline Accounting* & Intermediate Accounting I or Management Accounting \\
\hline Accounting & Processing Control/Internal Control \\
\hline Accounting & Accounting Information Systems \\
\hline Information Systems & Introduction to Computers \\
\hline Information Systems & Computer Programming \\
\hline Information Systems & Systems Analysis \& Design \\
\hline Information Systems & Data Base Management Systems \\
\hline Information Systems & Computer-based Communication Networks \\
\hline Information Systems & Management of Information Systems \\
\hline Auditing & Internal Auditing I \\
\hline Auditing & Introduction to Information Systems Auditing/CAATs \\
\hline Auditing & Special Topics (See Table 4). \\
\hline grams require both sophomore courses as prerequisites, we did not include the scores on these courses in our computation. \\
\hline
\end{tabular}

As financial data and information are stored and communicated using the computer, it becomes apparent that the lack of computer programming skills may handicap accountants in working effectively as IS auditors. In this regard, the ISACA's Task Force for the model curriculum expressed the following sentiment (ISACA, 2000c): 
"In the computer programming course, languages such as $C++, 4 G L, C O B O L$ or others are usually covered. An additional course might be desirable, although more advanced courses, such as computer based communications networks, can include additional technical or object-oriented programming languages such as JAVA or ActiveX. Furthermore, general knowledge of operating systems programming issues, client/server, the Internet/Intranet and other current global networking issues are important. IS related courses provide both exposure to, and awareness of, the complexities of information technology (IT) operations and the management of IT. For example, courses may include discussion on IT project management, and/or IT risk management, recognizing success and failure factors in IT related projects. Also, these courses would include modern emerging issues such as the technology enabled extended enterprise, electronic commerce and the Internet/Intranet."

The need for fundamental programming skills for AIS graduates is analogous to the need for introductory financial accounting courses in accounting programs. In principles of financial accounting, accounting students are introduced to the language, fundamental concepts, methods, and basic thought processes in accounting. This prepares them for the remainder of the curriculum, in which more advanced concepts, methods, tools, and thought processes are developed and refined. In the same way, a working knowledge in computer programming or application development sets the foundation and engages the required thought processes for work in the information systems area.

The primary lesson learned in various IS classes is how to productively implement various business ideas by automating business processes through analysis, design, development, evaluation, and management of information systems. In short, a working knowledge of programming offers AIS students a strong foundation for developing the types of skills and thought processes needed by future accounting information services consultants and auditors.

\section{ISACA's Graduate Model Curriculum}

Tables 2, 3, and 4 presents ISACA's graduate model curriculum, which offers a rich set of options for AIS program designers. ISACA designed the model graduate curriculum to enable graduates to experience a far deeper and broader spectrum of courses than the undergraduate model curriculum. ISACA expects that AIS graduate degree candidates will have studied and/or have had 1-5 years experience in IS, accounting, business, commerce, finance, or IT related engineering. At a minimum, potential students qualifying for such a program are expected to possess an undergraduate business-related degree in IS, accounting, commerce, finance or a combination of these. In the graduate model curriculum, students deficient in either business education or experience (such as non-IS related engineering, arts, etc.) would generally be required to take prerequisite IS, business or commerce courses typically expected of first-year graduate business students (ISACA, $2000 \mathrm{c}$ ).

\section{AICPA's Model for IT Education}

The AICPA recommends that all professional accountants, irrespective of their primary work domain or role, acquire a general level of IT knowledge that includes the following five topical areas (AICPA, $2000 \mathrm{e}$ ):

IT concepts for business systems

Internal control in computer based business systems

Development standards and practices for business systems

Management of IT adoption, implementation, and use

Evaluation of computer based business systems 
Table 2

ISACA's Graduate Model Curriculum for Certified Information Systems Audit (CISA) Professionals*

\begin{tabular}{|l|l|}
\hline Domain Area & Courses \\
\hline Basic Understanding & Information Systems Management or Auditing Practice and Theory \\
\hline Basic Understanding & International Business or Business Organization/Finance \\
\hline Basic Understanding & Information Systems Auditing \\
\hline Required IS Auditing & Legal Environment in Information Systems \\
\hline Required IS Auditing & Security \& Privacy in Information Systems \\
\hline Required IS Auditing & Networks \& Telecommunications \\
\hline Required IS Auditing & Advance IS Auditing/CAATs \\
\hline Directed Electives* & Elective I: A Course in Table 4 \\
\hline Directed Electives* & Elective II: A Course in Table 4 \\
\hline Directed Electives* & Elective III: A Course in Table 4 \\
\hline Business Research Methods and Project/Thesis & Business Research Methods and Application \\
\hline Business Research Methods and Project/Thesis & Business Research Project, Thesis, Comprehensive Exam or Capstone Class \\
\hline
\end{tabular}

Table 3

Areas to be included in the Required IS Auditing-Related Courses -- ISACA's Model*

\begin{tabular}{|l|l|}
\hline Topical Area Number & Topical Area \\
\hline 1 & Information technology and use \\
\hline 2 & Systems analysis, design, development, purchase and implementation \\
\hline 3 & Internal control and documentation of IS \\
\hline 4 & Data structures and data base concepts and management \\
\hline 5 & Information systems applications and processing cycles \\
\hline 6 & Management and monitoring of IS \\
\hline 7 & Computer programming languages and procedures \\
\hline 8 & Communications and networks; \\
\hline 9 & Model based systems (decision support and expert systems) \\
\hline 10 & Systems Security and disaster recovery planning \\
\hline 11 & Auditing of IS and its role in business \\
\hline
\end{tabular}

*Table adapted from ISACA (2000c).

This level of knowledge is expected to be covered in the first introductory business computing or AIS course. However, this basic background is ordinarily insufficient to support the new demands for high quality information services consultants and auditors.

Recognizing the relatively weak IT background of many CPAs, the AICPA recently designed a much more rigorous body of knowledge for accounting professionals who wish to provide information systems services. Persons who demonstrate competence in this more rigorous body of knowledge, shown in Table 5, receive the AICPA's Certified Information Technology Professional designation (AICPA, $2001 \mathrm{c}$ ). In the long run, as noted in the AICPA's IT Competences in Accounting Profession (AICPA, $2000 \mathrm{f}$ ), the scope and contents of the body of knowledge necessary for quality information systems assurance services will undoubtedly expand.

\section{Research Questions}

Given the nature of the factors that drive the need to reexamine the AIS curriculum, as well as the extensive recommendations and model urricula of ISACA and the AICPA, it seems that the most effective approach to AIS 
Table 4

Special Topics for Directed Electives -- ISACA's Model*

\begin{tabular}{|l|l|}
\hline Topical Area Number & Topical Area \\
\hline 1 & Executive Information Systems \\
\hline 2 & Rapid Systems Development \\
\hline 3 & Information Systems Planning \\
\hline 4 & Advance Systems Analysis and Design \\
\hline 5 & Wide Ares/Voice Networks \\
\hline 6 & Software Quality Assurance \\
\hline 7 & Business Systems Analysis \\
\hline 8 & Network Management \\
\hline 9 & Human Factors in Systems Design \\
\hline 10 & Business Economics \\
\hline 11 & Advance Office Systems/Directed Study \\
\hline 12 & Managerial Accounting for Decision Making \\
\hline 13 & Database Design and Processing \\
\hline 14 & Executive Development \\
\hline 15 & Professional Presentation Using Technology/Directed Study \\
\hline 16 & Management Science/Directed Study \\
\hline 17 & Advance Financial Management/Directed Study \\
\hline 18 & Accounting for Decisions and Control/Directed Study \\
\hline 19 & IS Integrity, Confidentiality and Availability \\
\hline
\end{tabular}

Table 5

AICPA's Recommended Body of Knowledge for Certified Information Technology Professional (CITP)*

\begin{tabular}{|l|l|}
\hline Domain Area & Topical Area \\
\hline Accounting/Auditing & Systems Auditing/Internal Control \\
\hline Accounting/Auditing & Security, Privacy and Contingency Planning \\
\hline Information Systems & Information Technology Strategic Planning \\
\hline Information Systems & Systems Architecture \\
\hline Information Systems & Information Systems Management \\
\hline Information Systems & Business Applications and E-Business \\
\hline Information Systems & System Development, Acquisition, and Project Management \\
\hline Information Systems & Databases and Data Base Management \\
\hline
\end{tabular}

*For more details on each topic, see http://citp.aicpa.org/bok.htm

education is to offer full-fledged AIS degree programs. We define a full-fledged AIS program as a degree program or concentration in the area of accounting/financial information systems, information systems audit, or an equivalent academic program. Currently, little is known about the existence and/or nature of such programs at AACSB accredited business schools.

The remainder of this paper describes the methodology and findings of a survey of AACSB accounting programs. The goal of the survey was to examine accounting programs to learn the extent to which they have been influenced by the changing AIS environment and the apparent need for full-fledged AIS programs to effectively train and educate students. Both the AICPA and ISACA guidelines are used as models for assessing the current state of AIS curricula at US universities. The objective of this assessment is to provide insight regarding the degree to which ideas from those publicly available model curricula are incorporated into AIS programs. The following research questions are examined:

1. What proportion of business schools with separate accounting AACSB accreditation offer full-fledged AIS programs?

2. Are departments that offer full-fledged AIS programs multidisciplinary?

3. Do multi-disciplinary accounting departments offer non-AIS information systems degrees? 
4. To what extent do departments that offer full-fledged AIS programs incorporate into their curricula ideas from publicly available models for AIS education?

\section{Data Collection And Research Methodology}

In order to explore the research questions examined in the paper, we collected curricula data from each institution with separate accounting AACSB accreditation by accessing their World Wide Web pages during the fall semester of 2000. This approach to data collection is likely to misrepresent AIS programs at institutions with dated Web sites, as well as institutions with updated or newly designed AIS programs that were not yet approved for Web publication. Therefore, we confirmed the data by writing to accounting department chairs at each institution included in the Web survey and requesting copies of their most recent accounting and AIS curricula. We observed no major differences between program documentation obtained from the Web and the program documentation we received from accounting department chairs.

We classified the various IS programs ${ }^{1}$ at AACSB-accounting accredited institutions into two major groups: (1) AIS, and (2) management information systems (MIS). We grouped all IS programs related to accounting, finance, or risk assurance into AIS, and grouped the remaining programs into the MIS group. As AIS and MIS evolve and become more specialized, we recognize that future classifications might develop along different lines. For instance, the major AIS activities of analysis, design, development, evaluation, use, and management of financial information systems could form the basis for a classification scheme. Similarly, major MIS activities such as the analysis, design, development, evaluation, use, and management of management information systems could form a basis for MIS classification. We also recognize that some of the activities in AIS and MIS are bound to overlap and interact each other, causing future classification difficulties.

We developed a point system to facilitate assessment of the extent to which full-fledged AIS programs incorporate published curricula ideas from ISACA and the AICPA. For each course offered in the AIS program, we allocate one point to each course that is recommended in either the ISACA's model curricula or the AICPA's body of knowledge. If both the ISACA and AICPA models recommend an area, then we allocate two points. If the course content or level of knowledge can be found at the sophomore level of a typical AACSB-accredited business school, then we do not allocate any points. This restriction resulted in us not allocating any points to courses such as principles of accounting, introductory business computing, or equivalent levels of courses. Since not every accounting student is required to take computer programming courses (even though some may be offered at the sophomore level), and because these courses are not often used to satisfy general business requirements, we allocated one point to such courses. We recognize that our point system is not necessarily an indicator of program quality, as some accounting departments may elect to create programs that are customized to fit their own unique contexts. Nonetheless, given that quality might be defined in terms of the degree of conformance to a desired norm, then one can make the case that conformance to these guidelines is a measure of quality.

\section{Findings}

One surprising finding is that there are very few full-fledged AIS degree programs among AACSBaccounting accredited universities. As shown in Table 6, only twelve institutions with separate AACSB accreditation in accounting (8.11 percent) offer full-fledged AIS programs at the undergraduate level. Eight institutions (5.41 percent) offer full-fledged graduate AIS programs. Among them, only four universities offer full-fledged AIS programs at both the undergraduate and graduate levels. Considering the numerous IT-related factors that are affecting the work of accounting professionals, as well as the strong demand in the business community for IS auditors and IT professionals, in general, we find the scarcity of AIS programs to be quite surprising.

\footnotetext{
${ }^{1}$ The authors elected not to include their university in this study. Their University recently started full-fledged AIS programs at both the graduate and undergraduate levels.
} 
Table 6

Universities that Offer Full-Fledged AIS Programs

Among 148 Universities with AACSB - Accounting Accredited Programs

\begin{tabular}{|c|c|c|c|}
\hline Universities & Department Names & $\mathbf{U G}^{*}$ & $\mathbf{G}^{*}$ \\
\hline Arizona State University & School of Accountancy and Information Management & $\mathrm{N}$ & $\mathrm{Y}$ \\
\hline Bentley College & Accountancy & $\mathrm{Y}$ & $\mathrm{Y}$ \\
\hline Bowling Green State University & Accounting and Management Information System & $\mathrm{Y}$ & $\mathrm{N}$ \\
\hline Central Michigan University & School of Accounting & $\mathrm{Y}$ & $\mathrm{N}$ \\
\hline Cleveland State University & Accounting and Business Law / Computer Information Systems & $\mathrm{N}$ & $\mathrm{Y}$ \\
\hline James Madison University & School of Accountancy & $\mathrm{Y}$ & $\mathrm{N}$ \\
\hline Oakland University & Accounting and Finance Dept. & $\mathrm{Y}$ & $\mathrm{Y}$ \\
\hline Oklahoma State University & School of Accounting / Management Dept. & $\mathrm{N}$ & $\mathrm{Y}$ \\
\hline The University of Kansas & Accounting and Information Systems & $\mathrm{N}$ & $\mathrm{Y}$ \\
\hline The University of Southern Mississippi & School of Professional Accountancy and Information Systems & $\mathrm{Y}$ & $\mathrm{N}$ \\
\hline The University of Texas at Arlington & Accounting & $\mathrm{Y}$ & $\mathrm{N}$ \\
\hline University of Delaware & Accounting and Management Information System & $\mathrm{Y}$ & $\mathrm{Y}$ \\
\hline University of Massachusetts-Amherst & Accounting and Information Systems & $\mathrm{Y}$ & $\mathrm{N}$ \\
\hline University of Nevada-Reno & Accounting and Computer Information Systems & $\mathrm{Y}$ & $\mathrm{N}$ \\
\hline University of North Texas & Accounting & $\mathrm{Y}$ & $\mathrm{N}$ \\
\hline Virginia Polytechnic Institute and State University & Accounting and Information Systems & $\mathrm{Y}$ & $\mathrm{Y}$ \\
\hline \multicolumn{2}{|c|}{ Total number of institutions with full-fledged AIS programs } & 12 & 8 \\
\hline \multicolumn{2}{|c|}{ Percent of all 148 institutions with separate AACSB accounting accreditation } & $8.11 \%$ & $5.41 \%$ \\
\hline
\end{tabular}

$* U G=$ Undergraduate programs; $G=$ Graduate programs

As implied by their names, the majority of departments that offer full-fledged AIS programs are multidisciplinary. Table 6 shows that, as suggested by ISACA and the AICPA, most business schools that offer full-fledged AIS programs (58 percent undergraduate and 88 percent graduate) have combined accounting departments with computer information systems and/or management information systems departments. A small number of these multidisciplinary departments also offer traditional MIS degrees at both graduate and undergraduate levels. Among the 148 institutions with separate AACSB accreditation in accounting, close to eight percent of all MIS degrees (graduate and undergraduate) are offered in these multidisciplinary accounting departments.

Table 7

Undergraduate and Graduate MIS Programs Offered Among 148 Universities with separate AACSB Accounting Accreditation

\begin{tabular}{|l|c|c|c|}
\hline & $\begin{array}{c}\text { Total number of MIS } \\
\text { programs offered }\end{array}$ & $\begin{array}{c}\text { MIS Programs offered in multidisciplinary } \\
\text { accounting departments }\end{array}$ \\
\cline { 2 - 4 } & & $\underline{\text { Number }}$ & $\underline{\text { Percent }}$ \\
\hline Undergraduate MIS Program & 151 & 13 & $8.61 \%$ \\
\hline Graduate MIS Program & 128 & 9 & $7.03 \%$ \\
\hline Total undergraduate and graduate programs & 279 & 22 & $7.89 \%$ \\
\hline
\end{tabular}


Based on the scoring method described earlier, we computed total scores for each university that offers a full-fledged AIS program at both undergraduate and graduate levels. Table 8 shows that most departments that offer full-fledged AIS programs have incorporated, in varying degrees, the recommendations ISACA and the AICPA. Based on the standard deviations of the scores shown in Table 8 (Panels A and B), there seems to be more variability at the undergraduate level than at the graduate level regarding the extent to which these proposals have been integrated into full-fledged AIS programs. At the undergraduate level, Virginia Polytechnic Institute and State University, Bentley College, Bowling Green State University, and Central Michigan University are the most advanced in terms of the extent to which ideas from the ISACA and AICPA models are incorporated into their programs. At the graduate level, Virginia Polytechnic Institute and State University and Bentley College are the most advanced in terms of incorporating AICPA/ISACA guidelines into their program.

Table 8

Extent to which ISACA and AICPA Models are Incorporated into AIS Programs

Panel A: Undergraduate AIS Program

\begin{tabular}{|l|l|c|}
\hline Universities & Department Names & Scores \\
\hline Bentley College & Accountancy & 11 \\
\hline Bowling Green State University & Accounting and Management Information System & 10 \\
\hline Central Michigan University & School of Accounting & 10 \\
\hline James Madison University & School of Accountancy & 8 \\
\hline Oakland University & Accounting and Finance Dept. & 3 \\
\hline The University of Southern Mississippi & School of Professional Accountancy and Information Systems & 8 \\
\hline The University of Texas at Arlington & Accounting & 5 \\
\hline University of Delaware & Accounting and Management Information System & 4 \\
\hline University of Massachusetts-Amherst & Accounting and Information Systems & 5 \\
\hline University of Nevada-Reno & Accounting and Computer Information Systems & 7 \\
\hline University of North Texas & Accounting & 6 \\
\hline Virginia Polytechnic Institute and State University & Accounting and Information Systems & 13 \\
\hline Standard deviation of scores & & 3.06 \\
\hline
\end{tabular}

\section{Panel B: Graduate AIS Program}

\begin{tabular}{|l|l|c|}
\hline Universities & Department Names & Scores \\
\hline Arizona State University & School of Accountancy and Information Management & 7 \\
\hline Bentley College & Accountancy & 10 \\
\hline Cleveland State University & Accounting and Business Law / Computer Information Systems & 8 \\
\hline Oakland University & Accounting and Finance Dept. & 4 \\
\hline Oklahoma State University & School of Accounting / Management Dept & 6 \\
\hline The University of Kansas & Accounting and Information Systems & N/A* \\
\hline University of Delaware & Accounting and Management Information System & 4 \\
\hline Virginia Polytechnic Institute and State University & Accounting and Information Systems & 10 \\
\hline Standard deviation of scores & & 2.87 \\
\hline \\
\multirow{2}{*}{$\begin{array}{l}\text { score } \text { score was computed for this program because it includes numerous electives that made it difficult to obtain a meaningful } \\
\end{array}$}
\end{tabular}




\section{Discussion And Conclusion}

In this study, we find that there exists a surprisingly small number of AIS programs among universities with AACSB-accounting accreditation - and an even smaller number of programs that fully incorporate curricula ideas from ISACA and the AICPA into their AIS programs. Considering the strong demand for AIS services in the marketplace, it seems evident that there are opportunities for development of new full-fledged AIS programs.

The paucity of AIS programs may be explained by the historical absence of a professional organization that serve to champion the growth and development of AIS (Cheh, 2000). Cheh argued that the slow growth of AIS as a discipline, especially when compared to the growth in management information systems (MIS), might be due to the nonexistence of a professional organization dedicated to the growth of AIS. Recognizing that the American Accounting Association has two sections that should be dedicated to the growth and development of AIS, Cheh used Christensen's (1997) study of industrial organizations to support his argument. Christensen found that the dominant influence of major business lines in a company hinders an innovative minor business line until it is often too late to be recognized, resulting in the failure of the company to effectively compete in the next wave of technological innovation. Cheh compared the "innovator dilemma" case to the current situation within the American Accounting Association (AAA). Although the market demand for AIS graduates may exceed that for traditional accounting majors on several dimensions, historically the AAA has not (as an organization) focused on the growth and development of AIS and there has been no dedicated movement or clear strategy to support growth of AIS education within the AAA as an organization-wide priority.

Although the focus of this paper is on undergraduate and masters programs, there are implications for doctoral programs in accounting. As accounting departments strengthen their undergraduate and masters-level AIS programs to respond to the many factors that drive the need for AIS education, we anticipate an ever-increasing demand for Ph.D.s who are trained to teach accounting information systems. If the anticipated demand for AIS educators is not met by accounting programs, the demand may be met by those schools supplying Ph.D.s in Information Systems areas other than AIS.

\section{Limitations and Implications for Additional Research}

This paper brings up several issues that warrant future attention. As AIS programs across the nation grow, studies similar to this one might be used to provide guidance for AIS educators who wish to design or update their AIS programs. Though the current study provides insight into the extant state of AIS, it may be premature to rely exclusively on its findings as a basis for designing a new AIS program. The assessment conducted in this study relies on two normative models for AIS education, and does not explicitly consider market forces. In the future, the market for AIS graduates may provide additional evidence of the characteristics of successful AIS programs. Given the ever-changing nature of the IT and the associated demand for IT services, there is no guarantee that the current prescriptive ISACA and AICPA models will be effective.

Another issue that needs to be addressed is the optimal balance between computer programming and less technical areas in an AIS program. Although ISACA recognizes the need for computer programming and other technical content in AIS programs, some full-fledged AIS programs tend to place more emphasis on behavioral and management aspects of AIS and less emphasis on programming and technical content. Future researchers may seek to categorize AIS programs based on their technical versus managerial and behavioral emphases, and assess the marketability of students who graduate from programs with different emphases. This approach might be equally useful in assessing the current state of AIS as the approach used in this current study.

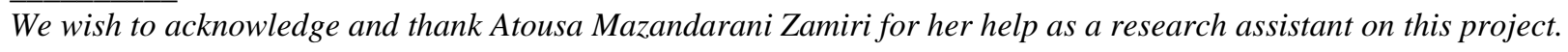




\section{References}

1. AACSB - The International Association for Management Education, Accredited Accounting Programs, Available online: http://www.aacsb.edu/Accred/Accounting/acctng.html (Accessed Sept. 23, 2000).

2. Albrecht, W. Steve, and Robert J. Sack, 2000, Accounting education: charting the course through a perilous future, Accounting Education Series, Vol. No. 6, American Accounting Association, Sarasota, Florida.

3. American Institute of Certified Public Accountants, Assurance Services, Available online: http://aicpa.org/assurance/index.htm (Accessed January 6, 2001 a).

4. American Institute of Certified Public Accountants, Center for Certified Information Technology Professionals, Available online: http://citp.aicpa.org/ (Accessed January 4, 2001 b).

5. American Institute of Certified Public Accountants, Certified Information Technology Professionals' Body of Knowledge, Available online: http://citp.aicpa.org/bok.htm (Accessed January 4, 2001 c).

6. American Institute of Certified Public Accountants, Challenge to Educators, Available online: http://www.aicpa.org/members/div/infotech/itc/cap22.htm (Accessed December 22, $2000 \mathrm{~d}$ ).

7. American Institute of Certified Public Accountants, Information Technology Competencies in the Accounting Curriculum, available online: http://aicpa.org/members/div/infotech/itc/acidx.htm (Accessed January 6, 2000 e).

8. American Institute of Certified Public Accountants, Information Technology Competencies in the Accounting Profession, available online: http://aicpa.org/members/div/infotech/itc/index.htm (Accessed January 5, $2000 \mathrm{f}$ ).

9. Botosan, Christine A. 1997. Disclosure Level and the Cost of Equity Capital. The Accounting Review,72 (July): 323-349.

10. Cheh, John J., 2000. Innovator's Dilemma and an Association for Accounting Information Systems Educators. The Review of Accounting Information Systems Vol. 4, No. 4: 77-98.

11. Christensen, C. M. 1997. The Innovator's Dilemma: When New Technologies Cause Great Firms to Fail, Harvard Business Press, Boston, 1997.

12. CICA/AICPA, 1999. Continuous Auditing, Canadian Institute of Chartered Accountants, Toronto, Canada.

13. Cushing, B. E. 1989. "On the Feasibility and the Consequences of a Database Approach to Corporate Financial Reporting," Journal of Information Systems, spring: 29-52.

14. Extensible Business Reporting Language, Available online: http://www.xfrml.org/ (Accessed September 21, 2000).

15. Information Systems Audit and Control Association, Control objectives for information and related technology, Available online: http://www.isaca.org/cobit.htm. (Accessed September 20, 2000 a).

16. Information Systems Audit and Control Association, Control objectives for information and related technology, Available online: http://www.isaca.org/modelc1.htm (Accessed September 24, 2000 b).

17. Information Systems Audit and Control Association, Model Curricula for Information Systems Auditing at the Undergraduate and Graduate Levels, Available online: http://www.isaca.org/modelc1.htm. (Accessed December 22, 2000 c).

18. Securities and Exchange Commission, EDGAR Database of Corporate Information, Available online: http://www.sec.gov/edgarhp.htm (Accessed September 23, 2000 a).

19. Securities And Exchange Commission, Selective Disclosure and Insider Trading. August 15, 2000. Effective date: October 23, 2000. [Release Nos. 33-7881; 34-43154; IC-24599, File No. S7-31-99] (File name: 33-7881.htm) Available online: http://www.sec.gov/rules/final/33-7881.htm (Accessed December 27, 2000 b).

20. Seligman, D. 2000. 24-7 Accounting. Forbes (October 30): 146-148.

21. W3, Some early ideas for HTML, Available online: http://www.w3.org/MarkUp/\#historical (Accessed December 27, 2000).

22. Zweig, P. L., J. Verity, S. A. Forrest, G. Burns, R. Hof and N. Harris. 1996. "Beyond Bean-Counting," Business Week (October 28): 130-132. 
Notes 